\title{
Fotografía étnica ¿de exportación?
}

Andrea Aguad Investigadora, Centro Nacional del Patrimonio Fotográfico

La fotografía como testimonio de realidades pasadas es, probablemente, el documento más objetivo para conocer la historia. La cultura mapuche, mostrada a través del lente profesional extranjero, se nos hace conocida, pero a la vez distante. Los límites entre producción de una realidad y la vida cotidiana se alejan, generando escenarios que realzan exotismos.

Desde su aparición, la fotografía fue apreciada como el medio expresivo por excelencia para captar un acontecimiento histórico y se le consideró cada vez más como un testimonio objetivo de la realidad; el medio más natural, transparente y directo de acceso a lo real (Berger, 1980). En el área de la antropología la fotografía etnográfica se utilizó desde sus inicios para dar un testimonio de veracidad. Se transformó en documento irrebatible de la realidad para observar los estilos de comportamiento perceptibles visualmente.

Dentro del registro de la realidad indígena existe un conjunto de fotografías que suponen una fidelidad histórica y que se han ido legitimando con el tiempo en estudios antropológicos, con su consecuente exhibición y circulación. Aparecen estas imágenes como el referente de una reivindicación étnica y exaltación de lo exótico.

Sin embargo, una gran parte de esta fotografía sobre pueblos originarios -o retratos etnográficos- nos muestra un panorama ideal de cómo ellos se ven y cómo se relacionan con nosotros y con las cosas. Pero en realidad, ¿qué ilustran estas fotografías? Parecen ser fieles retratos de arquetipos dados por la historia; ¿cómo se llegó a estas imágenes?

Estos sujetos, que hoy reconocemos y asignamos a través de fotografías como nativos, serían mucho más que el resultado de un registro de cierta realidad histórica y cultural. Como sujetos representados en una imagen serían la consecuencia de la materialización visual de la mirada del fotógrafo; éste, como productor de la imagen, despliega ciertos dispositivos y procedimientos para la construcción visual de lo étnico con una estética o una apariencia que muchas veces supera la historia. "Siguiendo este planteamiento, podemos afirmar nuevamente que las relaciones de producción tienen preponderancia sobre los medios de producción, ya que al convertir al sujeto en objeto no es el producto de ningún proceso técnico; sino que se produce más bien a través de una relación específica entre seres humanos, en donde uno desfigura e incluso deforma al otro, al imponerle una carga 'etnográfica' materializada en una estética determinada" (Alvarado, Mason; 2001).

¿Cuál es el común denominador de las imágenes que los retratan?, ¿qué nos hace considerarlas como fotografías étnicas? Son nativos precisamente porque corresponden a su representación, a un arquetipo históricamente dado, a un modelo anterior.

La fotografía étnica generalmente no retrata el comportamiento natural del sujeto, sino lo que el fotógrafo considera que tiene el valor informativo para reconocerlo como indígena. Desde los inicios de esta práctica, la construcción estética se basaba prin-
Photography as a witness of past realities is, probably, the most objective document for knowing history. The mapuche culture, shown through this professional foreign lens, has been made known albeit distantly. The limits between production of a reality and everyday life are distanced, generating scenes that highlight the exotic.

cipalmente en dos recursos: la escena y la pose. El montaje fotográfico buscaba escenificar un espacio determinado de modo de producir un específico efecto ambiental. Para reafirmar esta dramatización, el fotógrafo utilizaba objetos etnográficos -ollas, cántaros, cestos, piedras, lanzas, plumas, joyas- y así aparece ante nuestros ojos un indígena hiperritualizado. "Este montaje escenográfico lograba generar una atmósfera convincente, donde el retratado se sumergía en una materialidad indiscutible que reafirmaba su condición, produciendo la semejanza entre realidad y representación que todo retrato tenía como objetivo fundamental" (Alvarado, 2001).

Característica esencial de estas representaciones es la no individualización de los retratados. "¿Quiénes son estos sujetos fotografiados? Son sólo representantes de un mundo salvaje y exótico, son personajes que nos revelan otra cultura y otro comportamiento social, pasando a constituir un registro etnográfico de esa otra realidad" (Alvarado, 2001)

El sujeto retratado aparece entonces como el otro, es la alteridad, como la evidencia de una cultura diferente. Son anónimos personajes que pierden su individualidad justamente porque el retrato-montaje señala la distancia con ellos. Se les arranca de su propia realidad iconográfica y se les inserta en un nuevo contexto fotográfico, presentándose como una cita. Pero, ¿una cita de qué exactamente? Y si es una imagen de exportación, ¿a quién va dirigida?, ¿bajo qué condiciones?, ¿cuál es esa otra realidad a la que no llegamos a través de estas representaciones? Desde esta perspectiva cabe preguntarse, ¿corresponden realmente estas fotografías de indígenas a lo que sabemos de ellos? ARQ

\section{Bibliografía}

Alvarado, Margarita y Peter Mason. "La desfiguración del otro. Sobre una estética y una técnica de producción del retrato etnográfico”. Aisthesis № 34. Instituto de Estética, Pontificia Universidad Católica de Chile, Santiago, 2001. / Alvarado, Margarita. Pose y montaje en la fotografía mapuche. Retrato fotográfico, representación e identidad. Pehuén Editores, Santiago, 2001. / Berger, John. Mirar. Ediciones La Flor, Buenos Aires, 1980.

\section{Pareja mapuche}

Obder Heffer Bissett. Colección Archivo Patrimonial Universidad Diego Portales.

02 Mujeres mapuches.

Gustav Milet Ramírez. Colección particular, c. 1890.

03 Mujer mapuche.

Gustav Milet Ramírez. Colección particular, c. 1890 

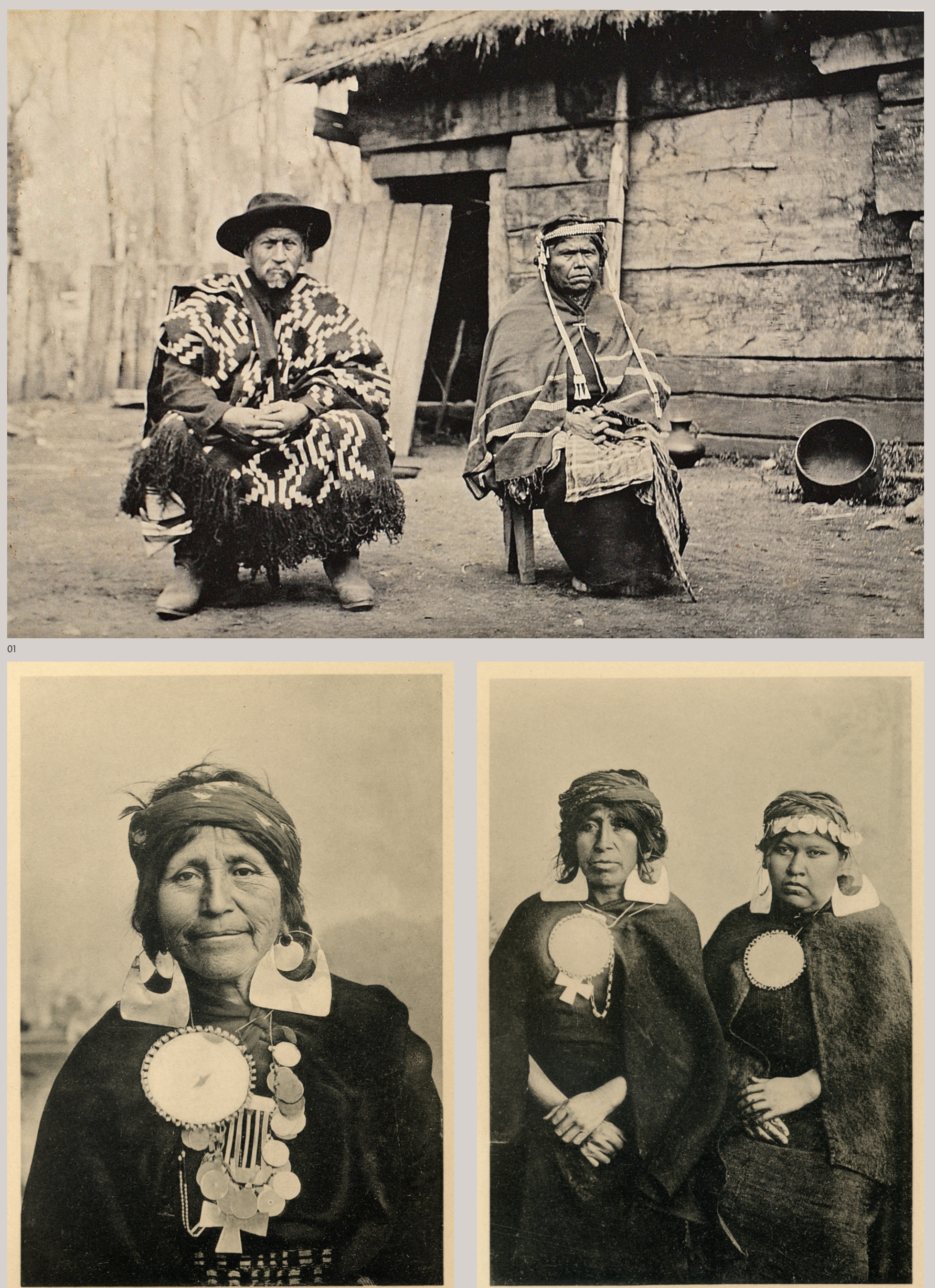